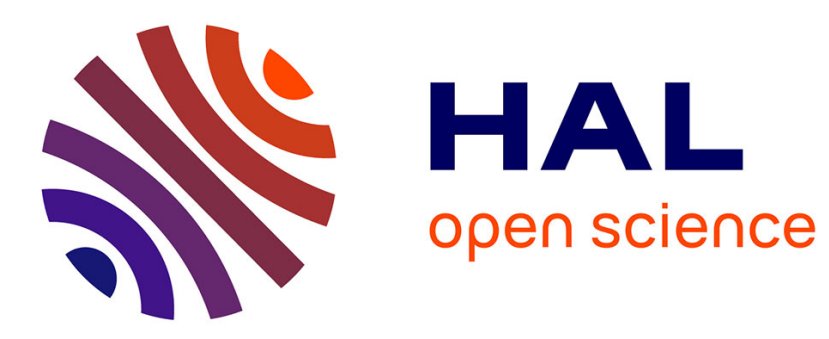

\title{
Regulation of milk protein secretion: PLD-dependent and -independent mechanisms
}

Raphaël Boisgard, Eric Chanat

\section{To cite this version:}

Raphaël Boisgard, Eric Chanat. Regulation of milk protein secretion: PLD-dependent and independent mechanisms. 668th Meeting of the biochemical society. Complex protein assemblies as molecular machines, Apr 1999, Glasgow, United Kingdom. , Biochemical Society Transactions, 27

(3), 1999, 668th Glasgow Meeting. hal-02764712

\section{HAL Id: hal-02764712 \\ https://hal.inrae.fr/hal-02764712}

Submitted on 4 Jun 2020

HAL is a multi-disciplinary open access archive for the deposit and dissemination of scientific research documents, whether they are published or not. The documents may come from teaching and research institutions in France or abroad, or from public or private research centers.
L'archive ouverte pluridisciplinaire HAL, est destinée au dépôt et à la diffusion de documents scientifiques de niveau recherche, publiés ou non, émanant des établissements d'enseignement et de recherche français ou étrangers, des laboratoires publics ou privés. 


\title{
Regulation of milk protein secretion: PLD-dependent and -independent mechanisms
}

\author{
R. Boisgard and E. Chanat. INRA, Laboratoire de Biologie \\ Cellulaire et Moléculaire. 78352 Jouy-en-Josas cedex, France.
}

Phospholipase D (PLD), which catalyses the hydrolysis of phosphatidylcholine to phosphatidic acid (PA), has been implicated in the regulation of membrane traffic in the secretory pathway. We have investigated the involvement of PLD in milk proteins secretion in mammary epithelial cells (MEC). Butanol (1\%), which inhibits the formation of PA, decreased the secretion of caseins by $50 \%$ whereas that of whey acidic protein (WAP) was reduced by only $30 \%$. On the other hand, $1 \mu \mathrm{M}$ phorbol $12,13-$ dibutyrate (PDBu), an activator of PKC, induced a differential increase in the secretion of caseins (15\%) and of WAP (40\%). The involvement of PLD was confirmed by showing a transphosphatidylation activity, this activity being increased by PDBu. PLD was found to act at two steps of the secretory pathway. First, analysis of protein maturation, which reflects their ER to Golgi transport, showed that butanol slowed down the transport of caseins but not of WAP. Second, the transport of caseins from the TGN to plasma membrane was reduced to 40\% when the formation of PA was inhibited, whereas that of WAP was less affected. Consistent with this decrease of casein secretion, electron microscopy revealed a dramatic reduction of casein-containing secretory vesicles in butanol-treated MEC. On the other hand, $\mathrm{PDBu}$ stimulated the secretion of both caseins and WAP from the TGN. In the presence of both PDBu and butanol, however, only the secretion of caseins returned to butanol level. Taken together, our results demonstrate the implication of PLD in casein transport through the secretory pathway of MEC and suggest that the secretion of WAP, in contrast to that of caseins, is independent of PLD. 